\title{
The Demystification of Magic in the Tafsīr al-Manār: An Analysis of the Exegetical and Homiletic Devices Used in the Discussion 'Mabhath al-sihr wa-Hārūt wa-Mārūt'
}

\author{
Stephen R. Burge
}

Citation: Burge, Stephen R.. 2021. The Demystification of Magic in the Tafsīr al-Manār: An Analysis of the Exegetical and Homiletic Devices Used in the Discussion 'Mabhath al-sih̀r wa-Hārūt wa-Mārūt'. Religions 12: 734. https://doi.org/10.3390/ rel12090734

Academic Editor: Marco Demichelis

Received: 11 August 2021

Accepted: 2 September 2021

Published: 7 September 2021

Publisher's Note: MDPI stays neutral with regard to jurisdictional claims in published maps and institutional affiliations.

Copyright: (C) 2021 by the author. Licensee MDPI, Basel, Switzerland. This article is an open access article distributed under the terms and conditions of the Creative Commons Attribution (CC BY) license (https:// creativecommons.org/licenses/by/ $4.0 /)$.
The Institute of Ismaili Studies, London N1C 4DN, UK; sburge@iis.ac.uk

\begin{abstract}
The two angels Hārūt and Mārūt are mentioned together with the prophet Solomon in the 'magic pericope' of Sūrat al-Baqara (Q. 2:101-103). Rashīd Rị̂a and his mentor Muhammad 'Abduh rejected the folkloric, mythical legends that surrounded the two angels Hārūt and Mārūt and the image of Solomon as a magus-like figure, seeing it as a threat to the rational interpretation of the Qur'ān. In his exegesis, Tafsīr al-Manār, Riḍā includes a relatively substantial tract denouncing magic and its use, entitled Mabhath al-sihr wa-Hārūt wa-Mārūt. This article will provide an analysis of exegetical and homiletic features used in this section, focusing on four areas: (i) elements of homiletic antisemitism; (ii) the invocation of personal experience; (iii) the use of lexicology to demystify Qur'ānic references to magic; and (iv) the use of a variant reading to demythologize the story. The aim of this article is to explore the ways in which the rejection of magic is articulated and which homiletic and exegetic tools Rị̂a uses to support his position. A final section will explore the modernist movement's relationship with biblical studies and the influence that it may have had on the interpretation of myth in the Tafsìr al-Manār.
\end{abstract}

Keywords: Rashīd Rị̣ā; Tafsīr al-Manār; magic; demystification; modernism; exegesis; homiletics; biblical studies

\section{Introduction}

In his exegesis of the Qur'ānic magic pericope (Q. 2:101-103) in the Tafsīr al-Manār, Muhammad Rashīd Rị̣ā (d. 1354/1935) includes a section entitled, 'Mabhath al-siḥr waHārūut wa-Mārūt' ('An Examination of Magic and Hārūt and Mārūt'; 'Abduh and Riḍā, 2002, pp. 1,345-55), in which he seeks to deny the existence of magic (sihr) and rejects its use in popular religious expressions of Islam. This article will present a close examination of this section within the Tafsīr al-Manār, analysing the exegetical and homiletic devices that Rashīd Ridāa, along with his mentor Muhammad 'Abduh (d. 1323/1905), employ in the development of their argument rejecting the existence of magic. The importance of this passage can be seen in the fact that Riḍā mentions it specifically in his introduction to Sūrat al-Baqara as one of twenty-one discussions of legal issues ('Abduh and Riḍā 2002, vol. 1, p. 101). As already mentioned, this discussion is related to the magic pericope seen in $Q$. 2:101-103, which reads:

So when a messenger of God came to them, confirming what they already possessed, a group among those to whom Scripture had been sent turned their backs upon the Book of God, pretending not to recognize it.

Instead, they followed what the devils had narrated during the reign of Solomon. But it was not Solomon who disbelieved; rather, it was the disbelieving devils. It was they who taught mankind sorcery and what was revealed to in Babylon to Harut and Marut. But these taught no one without first telling them: "We are a mere temptation, so do not disbelieve". Yet they learn from them what enables a man to separate a man from his wife. And they do no harm to anyone with 
their sorcery, save by God's leave. They learn what harms them and does them no good. They know full well that he who deals in sorcery has no share in the afterlife. Wretched is the price they pay for their souls, if only they knew!

Had they believed and feared God, the reward from God would have been best, if only they knew! (Khalidi 2008, p. 14)

In many respects, the Mabhath al-sihr does not provide an exegesis of this verse specifically, but Ridā uses the verse as a means to launch into a tangential discussion of magic in general, making this passage less of an exegesis and more of a sermon or religious tract, which reflects his own designation of this section at the beginning of Sürat al-Baqara. Indeed, this forms only a part of the treatment of the magic pericope, and the rest of the exegesis of verse, although much shorter, is rooted more firmly in the tafsir tradition, with a short paragraph preceding the Mabhath al-sihr, and the final four paragraphs being more typical of tafsìr material ('Abduh and Riḍā 2002, vol. 1, pp. 344-45, 354-55). Both the Majallat al-Manār and the Tafsìr al-Manār exhibit a mixture of styles, as Umar Ryad notes: 'From the time of its foundation, al-Manār became Ridā's life in which he published his reflections on the spiritual life, explanation of Islamic doctrine, endless polemics, commentary on the Qur'ān, fatwā-s, his thoughts on world politics, etc' (Ryad 2009b, p. 28). The Mabhath al-sihr is also a melding together of all of these aspects, where spirituality, doctrine, $\operatorname{tafs} \overline{\mathrm{i}}$, social commentary, and polemic flow into and out of each other.

The origins of the Tafsīr al-Manār are well known. Riḍa took the reflections and lectures of his teacher and mentor Muhammad 'Abduh and published them in the Majallat al-Manār (Yasushi 2006, pp. 17-19). 'Abduh provided material for Q. 1:1-4:125, but Riḍā continued to produce exegeses for the Manār until his death in 1935, by which time he had reached Q. 12:52. He published the exegetical material separately as the Tafsìr al-Manār in 1934. In the early stages, 'Abduh had sight of Ridā's work before it was published in the journal al-Manār, but after 'Abduh's death in 1905, Riḍa exerted increasing influence on the form and content of the exegesis. Pink estimates that some $85 \%$ of the Tafsīr al-Manār is Ridā's work (Pink 2016), and it is not always clear whether the views being represented are Ridā's own, or whether they are rooted in the opinions of 'Abduh. In respect to the Mabhath al-sihr, while it does include interpretative comments of 'Abduh, the broader scope of this particular passage appears to be almost entirely driven by Ridā: there is personal testimony offered by Riḍa and the passage has the flavour of a religious tract or fatwa. Consequently, the Mabhath al-sihr can be regarded as the product of Riḍā's mind, albeit drawing heavily on the thought of 'Abduh.

\section{Magic, Solomon, and the Two Angels Hārūt and Mārūt}

Before looking more closely at the Mabhath al-sihr, it will be helpful to place the discussion of this verse in its broader context, as this verse brings together three complex areas of Muslim tradition: the use and practice of magic, the prosopographical depiction of Solomon, and the folkloric tale of the two angels Hārūt and Mārūt. The magic pericope alludes to each of these, but without providing much in the way of detail or clarification. However, to further complicate the picture, each of these areas has a complex reception in Muslim theology and culture, with each being disputed in the classical period, and even more so in the move into modernity.

Throughout the medieval period, the use of magic was well known. While some Muslim scholars completely rejected the possibility of magic, others divided the 'magic arts' into those that were licit and those that were not (see Mol 2013). Some theologians maintained that some forms of magic were possible, whilst ' $[\mathrm{m}]$ any early and later classical scholars rejected the reality of sorcery and witchcraft, calling it forms of deceptions, illusions and trickery as the Arabic word sihr itself means "to make something false look real, deceit, falsification, delude"' (Mol 2013, p. 19). Those that accepted the existence of magic turned to a widely held tradition in the classical period that the Prophet was bewitched by a man called Labīd, for which the final two suras of the Qur'ān (Q. 113 and 114) were sent down to break the enchantment (see Burge 2015; Mol 2013). This use of the Qur'ān to break the 
bewitching of the Prophet fuelled the view that the words of the Qur'ân had apotropaic powers and were able to help cure illness, ward off the evil eye, and protect individuals from 'black' magic (Dols 1992, pp. 261-62; O'Connor 2016). In some cases, Muslims would write verses of the Qur'ān in ink, soak the paper in water and imbibe the water and ink to literally 'ingest' the Qur'ān and its power (Zadeh 2009). The use of talismans, including verses of the Qur'ān, was common in the classical period (Hamès 2017; Francis 2019), and remained so during the time that Riḍa and 'Abduh were publishing the Majallat al-Manār (Lane 2003, pp. 217-75). Such forms of magic rely on harnessing the divine power of God through the words of the Qur'ān. Other forms of magic, such as attempts to harness jinn for personal gain or to bewitch others, were not regarded as being licit, but were known in the classical and modern periods (Smith 1995).

The magic pericope locates magic (sihr) within the context of the prophet Solomon. In Jewish, Christian, and Muslim folklore, Solomon was often cast as a kind of magus with supernatural powers (Burge 2017). This was a particularly prominent aspect of his character in the late-ancient and early medieval periods, as seen in works such as the Greek Hygromanteia of Solomon (Torijano 1999), but it can also be found in Jewish apocryphal works, as well as in Muslim folklore, where hadith describe Solomon being able to command the winds, talk to animals, and bind demons (Burge 2017, pp. 315-18). The most famous 'magical' episode associated with Solomon in Islam is his encounter with the demon Sakhr, which is alluded to in Q. 38:34 and expanded greatly in both the Qisas al-anbiya' literature and in the Sira literature, discussed in more detail by Klar (2006) and Blatherwick (2016, pp. 116-35). This association of Solomon with magic is the first matter to be dealt with in the Mabhath al-sihr.

The second magical element that the magic pericope alludes to is the association of the two angels Hārūt and Mārūt with the 'dark arts'. The folklore around Hārūt and Mārūt is extremely complex, incorporating a number of different mythic strands that came to coalesce around them (Burge forthcoming). The most popular legend related about them explores the nature and meaning of being human (see Burge 2021). When God created Adam, the angels complained that God was creating another being 'who sows discord and sheds blood while we chant Your praises and proclaim Your holiness' (Q. 2:30). In response, God challenges the angels to experience being human for themselves. Having volunteered, the two angels Hārūt and Mārūt are sent down to earth to live as humans, where they live pious, holy lives for many years until they are seduced by a beautiful woman usually named as Zuhara or Zuhra (Venus). She tempts them to drink alcohol, after which they both commit murder, pray to her idols, and fornicate with her. God consequently punishes the two angels for their sins, but they are allowed to choose between punishment in this world or the next. They opt to be punished in this world as it will have an end, and, in many versions of the myth, they are then hung upside down in a cave. The story is one that explores the nature of sin, the human propensity to commit it, as well as the dangers of consuming alcohol and 'forgetting oneself'. This mythic story, which has many parallels with the accounts of the 'fall' of Adam and Eve, was incredibly popular and very widely transmitted, being cited in a wide range of classical works of tafsir , with the mythic story being included in the exegeses of al-Tabarī (d. 301/923), al-Tha 'labī (d. 427/1035), al-Māwardī (d. 450/1058), al-Baghawī (d. 516/1122), al-Maybūdī (d. ca. 520/1126), Ibn al-Jawzī (d. 597/1201), Fakhr al-Dīn al-Rāzī (d. 606/1210), al-Qurțubī (d. 671/1272), al-Bayḍawī (685/1286), al-Nasafĩ (d. 710/1310), Nizāām al-Dīn al-Nīsābūrī (d. 728/1328), Ibn Kathīr (d. 774/1373), al-Suyūṭī (d. 911/1505), and al-Burūsawī (d. 1137/1725). The muhaddith Ibn Hajar al- 'Asqalānī (d. 852/1449) also noted the wide array of isnāds that had transmitted story (see Burge 2012, p. 159).

The myth about the seduction and fall of Hārūt and Mārūt was mixed with another strand of traditions that describe a very different type of 'angelic fall'. In the Enochic literature, the rebellious angels, led by Lucifer, make a stand against the power and authority of God and descend to earth. There, they introduce the dark arts of magic and divination into the world as an act of defiance against God's sovereignty, in an attempt to 
subvert the natural order and to lead God's creations astray (see Reed 2004; Bauckham 1985), something which has more in common with the wish of Iblīs to lure God's creations away from the straight path (cf. Q. 15:41-42; 17:61-65; see Moad 2017). This tradition of the 'fallen angels' was also incorporated in the myths surrounding Hārūt and Mārūt, with the two angels, like the 'fallen angels' of the Enochic literature, being said to be the source of magic in the world. There are Muslim accounts of people seeking out the cave where Hārūt and Mārūt were hung upside down to learn the magical arts from them. However, there is an added layer of complexity: if an aspirant is able to locate Hārūt and Mārūt, the two agree to teach them magic, but only if they understand that by doing so they will become an unbeliever (käfir). For example, in his Qiṣaș al-anbiya $\bar{a}^{\prime}$ the Turkish writer al-Rabghūzī (d. after 710/1310) includes this description of aspirants seeking out the two angels to learn magic:

During the year when the point in time arrives that the angels had committed fornication, a man who has it in mind to learn magic will stay there on a dark night. He will communicate his plan in their language. They will reply, "It is a sin to learn magic; to practice it is blasphemy". If he does not accept this, they will say: "Go into the field and tell us what you see". He will go and squat down to relieve himself, and thus he will come to know. A white dove will emerge from his anus. He will return and tell them. They will say: "The white dove was your faith; it has left you. Know that you have learned magic". Now it will become clear that whoever learns magic and practices it has become a disbeliever in the Lord, he is mighty and glorious. (al-Rabghūzī 1995, pp. 1, 55)

This stark symbolic imagery links the learning of magic with unbelief, but also shows the angels acting as 'warners' (nadhìrs). This warning is alluded to at the end of Q. 2:102, in the words 'But these taught no one without first telling them: "We are a mere temptation, so do not disbelieve"'.

These two myths about Hārūt and Mārūt, the story of their seduction by Zuhara and their association with magic, come from very different traditions and have very different theological messages, but over time they came to be bound together. Along with the traditions about Solomon as a magus-like figure, there are then three strands of myth in Islam which are associated with magic in the Qur'ānic pericope. Of these three strands, the Mabhath al-siḥr ignores the story of the seduction of Hārūt and Mārūt by Zuhara. However, in the discussion of the phrase, 'Yet they learn from them what enables a man to separate a man from his wife' (Q. 2:102), there is some sense that this story may be being held in mind, but it is not mentioned directly ('Abduh and Ridā 2002, vol. 1, pp. 351-52). The Mabhath al-sihr does, however, refer to the association of Solomon and Hārūt and Mārūt with magic. Although it does not provide much in the way of detail about the myths that have just been described, elements in the mythic and folkloric stories associated with both the angels and the prophet Solomon would have been widely known by the readers of al-Manār, so it is important to be aware of these traditions when reading and analysing the Mabhath al-sihr.

This article will provide an analysis of the Mabhath al-sihr, focusing on four main areas, before drawing some broader conclusions: (i) elements of homiletic antisemitism; (ii) the invocation of personal experience; (iii) using lexicology and majāz to 'demystify' and 'rationalise' Qur'ānic references to magic; and (iv) the use of qira' $\bar{a}$ t to demythologize the story completely. The aim of this article is not to explore the rightness or wrongness of Ridā's argument, nor to locate the origins of his positions, but rather to explore the ways in which the rejection of magic is articulated and what types of homiletic and exegetic tools are being used to support his position.

\section{Homiletic Antisemitism}

Riḍā gives the folkloric image of Solomon as a magical figure very short shrift and rejects it wholeheartedly and completely. One of the tools he uses is a sustained polemic against Jewish thought, arguing that the image of Solomon as some sort of magus was introduced by the Jews. He writes: 
These delusions (awhīm) and lies ( $a k \bar{a} d h \bar{i} b)$ against the Prophet of God Solomon, peace be upon him, were fabricated by some of the swindlers (al-dajjāinn) of the children of Israel, and they prompted some amongst the Muslims to have doubts about him [and his character], and then they believed in some of what they had claimed about him regarding the accounts of magic'. ('Abduh and Ridā 2002, vol. 1, p. 346)

One of the most striking features of this short quotation is the vociferous attack against the 'swindlers of the children of Israel' (ba'd al-dajjālīn min bañ Isrā'îl) for introducing 'false beliefs' about Solomon. Such a position can be seen as part of the wider movement in modernist Islam to reject isrä'îliyyāt material, a position which had been held strongly by the Mamluk reformist Ibn Taymiyya (d. 728/1328; see Tottoli 1999). While 'Abduh was suspicious of isrā'îliyyāt material, Ridā was much stronger in his condemnation of it. Nettler comments that 'the common denominator of offensiveness in the Isra'iliyyat for [Ridā] were reported incidents that, in his view, were an embarrassing affront to human reason' (Nettler 1999, p. 5).

In the earlier days of the Majallat al-Manār, a more open view towards the Jews was adopted, with 'Abduh advocating a relatively inclusivist approach in some of his exegetical thinking (Shrenzel 2002; Bashkin 2021). However, Riḍa developed an increasingly negative view of the Jews and of Zionism over time (see Shavit 2015), seen particularly in his advocacy of a Palestinian revolt (Rid̄ā 1928). Although the passage cited above is principally aimed at a subset of unreliable Jews, elsewhere, this morphs into the Jews in general; Riḍa says things such as 'the Jews allege' ('Abduh and Ridāa 2002, vol. 1, p. 346), 'they mixed history with utter lies (dajl)' ('Abduh and Riḍā 2002, vol. 1, p. 346), and 'the Jews used to trace their magic back to two angels in Babylon' ('Abduh and Rị̂̄a 2002, vol. 1, p. 351), and so on. Such generic representations of Jews and their false and dangerous beliefs would have tapped into the growing antisemitism that was prevalent in early 20th century Muslim circles (Fastenbauer 2002). Importantly, the antisemitic elements in Rị̂̄'s argumentation function as an important homiletic and polemic tool in the rejection of magic: Riḍa creates a simple binary world in which the mendacious and deceitful Jews practice magic and the Muslims, who espouse the truth, do not.

Rị̣ā moves into a second attack based on prophetic infallibility (iṣma), where he argues that it is theologically impossible for Solomon to commit idolatry and to teach people magic, as both go against the law of God. Ridā criticises the Jews for even entertaining this idea, approaching this not simply as a theological principle but integrating it with polemic to further weaken the status of magic. Ridā's attack involves what appears to be an intentional conflation of two unrelated traditions about Solomon. The first is, as has already been seen, the belief that Solomon was some kind of magus and had magical powers. For most Muslim commentators, the magus-like image of Solomon is acceptable, since God, as creator, can both subvert natural law and can give someone else, such as Solomon, or Jesus, or Muhammad for that matter, the ability to subvert the natural order too (see Williams 2013; Thomas 2011). The second tradition that Riḍa alludes to is that Solomon committed idol worship. In 1 Kings 11, Solomon is said to have been corrupted by his foreign wives and, through lust and a desire to please them, bows down before their idols:

For when Solomon was old, his wives turned away his heart after other gods; and his heart was not true to the Lord his God, as was the heart of his father David. For Solomon followed Astarte the goddess of the Sidonians, and Milcom the abomination of the Ammonites. So Solomon did what was evil in the sight of the Lord, and did not completely follow the Lord, as his father David had done. (1 Kgs 11:4-6)

This story is developed in both Jewish and Christian traditions, the most important being the early Jewish pseudepigraphon, The Testament of Solomon (T. Sol. 26:1-6; Duling 1983). In most Muslim versions of this story, it is not Solomon who commits idolatry, but one of his wives, the daughter of Jarāda (Burge 2017, pp. 318-23). Although Solomon never actually commits idolatry in the Muslim accounts, he is rebuked by the prophet Asaph 
for allowing it to happen in his palace (al-Tha 'labī 2002, pp. 537-44). It should also be noted that 'Abduh had a general wariness about the authenticity of hadith and had an overwhelming preference to read the Qur'ān without such transmitted material (see Çoruh 2019, pp. 5-8). The belief that shirk was committed in Solomon's palace, as seen in works such as al-Tha 'labi's Qisas al-anbiya', are related through hadith and would have been regarded by 'Abduh as having potentially dubious authenticity and, consequently, being unsuitable for interpreting the Qur'ān.

In the Mabhath al-sihrr, Riḍa appears to conflate these two strands of tradition about Solomon. Riḍa portrays the accounts of Solomon's idolatry and Solomon's magical powers as being part of the same tradition. This seems to have been done intentionally, as it allows Riḍa to reject magic even more compellingly. If Solomon were able to perform miracles or do supernatural things, then that could potentially give magic some legitimacy. By bundling these two ideas together, Riḍa can use the obvious and clear 'error' (from the Muslim perspective) of the Jews in believing that Solomon committed idolatry to invalidate the potentially more acceptable idea amongst Muslims that Solomon had some degree of magic powers.

As one would expect in a tract such as the Mahbath fì siḥr, Riḍa moulds the material available to best represent his view. The firm rehabilitation of Solomon, including all rejection of any supernatural powers, demystifies the esoteric aspects of Solomon's prosopographical representation in folklore, creating a more rational and modernist view. At the same time, when this image of Solomon is placed in conjunction with the rejection of the biblical accusation of his idolatry, a deeper dichotomy between Muslims and Jews is created, entrenching the binary developed by Ridā around the Jews' acceptance of magic and the Muslims' rejection of it.

Towards the end of the Mabhath al-sihr, Ridā includes an extended discussion of lying and deceit which he extends to cover the differences between usury (riba) and charitable giving (zakā; 'Abduh and Riḍā 2002, vol. 1, pp. 352-53). The argument is primarily lodged against Muslim legal theorists, as Rị̂a comments:

Indeed we have seen many forbidden things (harramāt) being violated by Muslims through interpretations $\left(t a^{\prime} w \bar{\imath} l \bar{a} t\right)$ such as these, to the extent that some of those practising law have allowed one of the pillars of Islam to be torn down through a legal loophole (hĩla), namely the pillar of zakā ... ('Abduh and Riḍā 2002, vol. 1, p. 353)

This relatively long section may, at first, seem like a digression away from the issue of magic, but it reveals an important homiletic strategy. The reference to usury and deceit develops a discourse against the sinfulness of all forms of lying. Riḍa cites a number of hadith, including one which states: 'The verse of the hypocrites refers to three [people]: whenever he speaks, he lies; whenever he swears an oath, he reneges on it; whenever he is entrusted with something, he acts treacherously' ('Abduh and Riḍā 2002, vol. 1, p. 353). Magic, for Riḍa, is like usury: a mendacious act that is inherently sinful and inimical to Islam. The association of usury and lying with Jews were both common antisemitic tropes and ones that would have been known to readers of the Manār. This further cements the binary world that Ridā creates between the 'mendacious' Jews who developed magic and 'true' Muslims who do not believe in or practice magic.

\section{Personal Experience}

Although only mentioned in passing towards the end of his discussion of Solomon and magic, Riụa introduces an element of personal testimony. He writes:

Up to this day, you can see the swindlers of the Muslims, incanting oaths (aqsām) and spells $\left(a z \bar{a}^{\prime} i m\right)$. They cast divinations and talismans, and they called that the seal of Solomon (khätim Sulaymān) and his covenant. They allege that it protects the bearer from assaults from jinn ( $i^{\prime} t i d \bar{a}^{\prime}$ al-jinn) and attacks from devils (mass $a l$-'afärìt). The writer of this exegesis has seen something of this during the days 
of his youth, believing in it and accepting its advantages. ('Abduh and Riḍā 2002,

vol. 1, p. 346)

Riḍā's use of personal testimony is markedly different in tone to the types of testimony seen in reformist works written in the Mamluk period, such as those written by Ibn al-Hājj (d. 737/1336-7) and Ibn Taymiyya. Figures like these often describe the world in which they were living, detailing the things that offended them deeply, and explaining why such practices were inimical to Islam (Berkey 1995). Throughout these discourses, authors such as Ibn al-Hājj and Ibn Taymiyya remained as commentators and external observers, who knew how Muslims should behave and who felt it necessary to speak out and denounce the evils that had crept into Muslim society. Ridā, as well as other figures writing for al-Manār, such as 'Abd al-Hamīd al-Zahrawī (d. 1916) were, like Ibn Taymiyya (cf. Memon 1976), disapproving of aspects of popular religion, especially those linked to Sufism. The use of talismans and other such things as sources of protection from illness or the evil eye were common in popular expressions of religion in Egypt, which were often also associated with Sufism (see Lane 2003, pp. 217-75). Rị̣̂ā's attack against them can be seen as part of a broader campaign against popular religion (Commins 2006, pp. 43-46), which intensified in the later years of the publication of the Majallat al-Manār (see Elissa-Mondeguer 2002, p. 234).

There is, of course, an element of external observance in the way in which Ridā frames his personal testimony, but by confessing that he had once engaged in forms of magic and used talismans in his youth, the use of testimony forms a small, but key, part of his homiletic strategy. By admitting to having once believed in the efficacy of magic, Ridā is able to bring himself alongside his readers, and from there he is able to bring them with him when he explains the error in accepting and practicing magic. This is, by no means, an innovation of Ridā, and there are numerous examples of Muslim scholars admitting to past errors, from al-Ghazālī in his Munqidh al-dalāl to Muhammad 'Abduh's own personal testimony in his Risālat al-Wāridāt (Scharbrodt 2007), with Riḍā also devoting time to reflecting on his youth in his own autobiography (Sirriyeh 2000). However, here, Riḍa incorporates his personal testimony into the argument as a rhetorical and homiletic device to reaffirm his core message against magic.

In the latter part of the Mabhath al-sihrr, Ridā also includes an anecdote about an interaction that he had had with a scholar at the al-Azhar. Ridā says that

I remembered [a time] when I was writing out the hadith concerning the hypocrites; some of the well-known shaykhs of the al-Azhar [who were] with me [there] promised [to do something] for me, but they failed to keep it. I asked [Muhammad 'Abduh] about it, and he said: 'The Hanafi jurists among us say the fulfilling of a promise is not obligatory $(w \bar{a} j i b)^{\prime}$. Filled with anger, I said: 'Whoever puts forward this position (man yaqūlu hädhā al-qawl), having seen the fulfilment [of a promise] (al-wafā') and the warning against [not fulfilling] it (wa ' $\bar{\imath} d$ 'alā tarkihi) being mentioned explicitly in textual evidence (min al-nuṣuṣ al-ṣarīha), is wrong (mukhti') and his position should be rejected, as it was narrated in the Șah̄ị (indeed, I said more than this) ... ('Abduh and Rị̣ā 2002, vol. 1, p. 346)

Here, we see Ridāa arguing with his master 'Abduh and articulating his own, stronger position. Ridā is able to convey his outrage at the way in which the scholars of the al-Azhar had broken their promise to him, although he never says what the promise was or why it was important. Ridā's contempt seems to be driven particularly by the fact that this had all occurred during or after a discussion of the hadith about hypocrisy. Whether this actually happened or not is not important, but the reason for the inclusion of this anecdote is to allow Rị̣ā to emphasize his point about the impermissibility of lying in Islam. For Riḍa to break a promise is essentially to lie, regardless of what that promise was. Within the context of the Mabhath al-sihrr, where Ridā also equates magic with lying, the use of this 'real-life' anecdote enables him to articulate the strong position against lying and reaffirms his attack against magic.

Ridā was not simply an academic, but was a frequent speaker at events held throughout the Muslim world. Beyond the Tafsīr al-Manār, there are numerous examples of Riḍ̄̄'s 
skilful use of anecdotes in his speeches to convey and articulate key themes and messages (Zaman 2012, p. 113), which is what can be seen in this passage too. The personal confession given by Ridā is being used intentionally as a rhetorical device to help add more weight to the discourse being offered; likewise, his anecdote about the failed promises of some of the scholars at the al-Azhar is used to attack dishonesty as being un-Islamic, and by extension magic as well. Ridā employs anecdote and personal experience as homiletic devices, and although much more research would be required, it would be interesting to see the extent to which Riḍa utilizes anecdote in the Tafsìr al-Manār and when he chooses to employ it. Classical discussions of preaching practice highlight the importance of the character and manner of the person delivering a khutba, as this has a profound effect on the way in which the message could be received (Jones 2012, p. 244). However, personal opinion, in the form of a testimonial such as that given here, is rarer in classical formulations and theories of preaching. It is, of course, exceptionally rare to find personal testimony in either tafsì $r$ or fat $\bar{a} w \bar{a}$, highlighting the oral and homiletic basis of the Mabhath al-sihr.

\section{The Demystification and Rationalization of Magic in the Qur'an}

Although, as Zemmin has argued, creating clear boundaries between traditionalism, modernism, and reformism is problematic and does not reflect the complexity of what is going on in the reformism of al-Manār (Zemmin 2017, pp. 14-17), it is widely accepted that the reformism of 'Abduh and Riḍā sought to harmonize the world of the Qur'ān with scientific knowledge and rational thought (Çoruh 2019, pp. 4-5). As Yasushi comments, 'Tafsīr al-manār is an attempt to justify the reformulation of Islamic understanding of faith, society, life, and the world in modern days with its readings of the Quranic passages (Yasushi 2006, p. 17). This is seen particularly strongly in areas such as creation and evolution, where 'Abduh and Rị̂ā, as well as many other Muslim thinkers, read and interpreted Qur'ānic references to creation in line with emerging scientific theories, as discussed by Elshakry (2011) and by Adams (2010, pp. 138-40). 'Abduh and Riḍā tended to seek to provide rational solutions to passages in the Qur'ān which described seemingly supernatural elements, such as miracles (Adams 2010, p. 115; Kerr 1966, pp. 119-21; Zebiri 2000). So, for example, when the rods of Pharaoh's magicians are turned into snakes in Q. 7:108-120, a passage which generated much discussion in the tafsitr literature (Smith 2018) and which became an important feature in Islamic magic in the classical period (Fodor 1978), for 'Abduh and Riḍa this cannot be 'magic' and needs to be reinterpreted in some way.

The fact that the Qur'ān refers to magic and to the supernatural presented a problem for such a reformist and rationalist hermeneutic, so in order to address this problem, 'Abduh and Riḍa develop a process of rationalization or demystification. The aim is to show that when the Qur'ān refers to magic it is not actually referring to magic at all. This is achieved through two means: the first is to use lexicology to show that terms which would ostensibly appear to refer to magic do not necessarily carry meanings of enchantment and are not linked to the supernatural. This is followed by a second, more general, approach that argues for a metaphorical reading of all the verses that discuss magic. This second approach is common throughout 'Abduh's exegetical thinking, where he often seeks to draw out universal meanings; for example, he uses the story of David and Saul in Q. 2:249-253 to develop general theories about war (Adams 2010, pp. 141-42).

'Abduh begins this process of rationalization and demystification with an important passage that outlines the basic purpose of the Qur'ān as he sees it. He writes:

We have shown, more than once, that stories appear in the Qur'ān to teach (al-maw'iza) and to generate reflection (al-i'tibēr), they are not there to explain history, nor to bring about belief in the minutiae of the accounts about ages past ('inda 'l-ghäbirīn), but, rather, it is to come to a judgement about what can be understood regarding truth and falsehood, [what can be understood about] the truth and falsehoods in their narrations, and which of their customs were beneficial 
and [which were] damaging - for that reason they are for teaching and reflection.

('Abduh and Riḍ̄a 2002, vol. 1, pp. 346-47)

For 'Abduh, the primary goal of the Qur'ān is to generate teaching and reflection, and he encourages people to look beyond the details to see the main theological ideas that lie within; he also seeks to break free from the inherited tradition, by reading the text closely. For example, Shrenzel comments that regarding the term Islām that appears numerous times in the Qur'ān, 'Abduh seeks 'to understand the term Islām not as the established concrete religion but to stick to its literal meaning-"submission of the soul" and the "practical adherence to the orders of God"' (Shrenzel 2002, p. 217). 'Abduh extends this principle of demystification by commenting that 'when the sun sets, people living by the sea say "a disc of the sun fell into the sea" or "into the water"; but they do not [actually] believe that, rather they express it through what they see' ('Abduh and Ridā 2002, vol. 1, p. 347). Here, 'Abduh shows that what people say and the imagery that they use is not representative of what they actually think. Consequently, 'Abduh argues, interpreters of the Qur'ān need to be careful about how passages about magic are understood.

Regarding the meaning of the word sihr itself, 'Abduh turns to the meaning of the base of root. He argues that the Form I and the Form II of the root mean 'he deceived him' (khada 'ahu) or 'he distracted him' ('allalahu), removing any sense of magic ('Abduh and Rị̂a 2002, vol. 1, p. 347). For these more metaphorical readings of the root, he cites the example of referring to a woman as having an 'ayn sāhira, an 'enchanting eye' ('Abduh and Ridā 2002, vol. 1, p. 347), a metaphor that was common in the classical period (see Lane 1984, p. 1317); the eyes are not physically bewitching, they are simply very beautiful. To add further support, he cites a hadith in which the Prophet said, 'Some eloquent speech is as effective as magic' ('Abduh and Riḍa 2002, vol. 1, p. 347). He then examines the meaning of the form sahr, which refers to 'the opening and closing of the lungs' ('Abduh and Riḍ̂a 2002, vol. 1, p. 347), again a meaning found in the classical period (Lane 1984, p. 1316); this roots the meaning of the word in the natural and the everyday, rather than the supernatural. He also says that the term sāhir was used to refer to a scholar, so when the magicians at Pharaoh's court say 'O sorcerer (al-săhir), call on your Lord' in Q. 43:49, they meant 'scholar' or 'wiseman'. Such word games to demystify magic were not an innovation and can be found in discussions of magic in the medieval period as well (Mol 2013, pp. 17-18). Although many of these interpretations go against the grain of what the Qur'ān seems to be trying to say, what is more important is the fact that all these definitions seek to denude sihr of any sense of magic or bewitchment.

As Mol has shown, for 'Abduh magic is rooted in psychology and the way in which an individual interprets what he thinks he sees as being magic (Mol 2013, p. 22). Here, 'Abduh states that 'God has described magic in the Qur'ān as being something of the imagination (takhyill), which misleads the eyes, so one sees what is not there' ('Abduh and Riḍa 2002, vol. 1, p. 347). He goes on to say: 'All of these texts show that magic is either a ruse (hîla) or a sleight of hand (sha' wadha)' ('Abduh and Riḍā 2002, vol. 1, p. 347). Importantly, he describes the use of sleight of hand as something that can be learnt, i.e., something that is entirely human in origin, but to those who have not learnt it, when they see it 'its cause is unknown and its result is amazing' ('Abduh and Riḍa 2002, vol. 1, p. 347). To further defend his position, 'Abduh invokes unnamed historical sources that state that Pharoah's magicians used 'mercury to give the ropes and sticks the outward appearance of snakes and serpents, causing [people] to imagine what they wanted them to see' ('Abduh and Riḍā 2002, vol. 1, pp. 347-48). This sense of the witness's delusion and the practitioner's mendacity is highlighted towards the end of the Mabhath al-sihr, where the theme is expanded greatly ('Abduh and Riḍa 2002, vol. 1, pp. 352-53). Riḍa also comments: 'Indeed, they say this in order to make people believe that their knowledge is [from the] divine (ilāhiyya), that the things that they make are spiritual (rūhāniyya), that they have sound intentions' ('Abduh and Rị̣ā 2002, vol. 1, p. 348). Riḍa creates the image of those practicing magic and selling talismans as wilfully leading people astray, portraying them as confidence tricksters and snake oil salesmen, who deliberately delude the masses 
into thinking that the talismans and amulets they sell are rooted in the experience and sanction of the divine.

This process of the demystification of magic in the Mabhath al-sihr is achieved through a mixture of approaches. First, the words and language used for magic in the Qur'ān are weakened to such an extent that magic and enchantment simply become metaphorical for 'confusing' or 'confounding' other people. 'Abduh's view of magic is essentially the same as the way people view magicians performing on stage: people may be amazed at seeing someone disappear or being sawn in half, but it is simply a trick. Magic is simply an illusion where the viewer sees something that appears to be impossible and which appears to break the laws of nature; the viewer then interprets this in supernatural terms and responds with a sense of awe and wonder (cf. Lamont 2017). In his discussion of the Hanafi jurist al-Jașsạ̄ (d. 370/981), who wrote a treatise against magic, Zadeh comments that for Jașṣāṣ '[r] emaining astonished without uncovering the cause of the bewilderment is itself a form of ignorance' (Zadeh 2015, p. 245; see also Mol 2013, p. 19). 'Abduh takes a similar position: falling for a trick and not seeing the illusion of magic reveals the practitioner's abilities at sleight of hand, rather that revealing the supernatural; above all it is not a proof of magic, but a sign of the viewer's ignorance and failure to see and understand.

\section{Angels or Kings? The Use of Qira'āt}

After the digression into general principles about the non-existence of magic, the Mabhath al-sihr then returns to the magic pericope and focuses on the figures of Hārūt and Mārūt. This section demystifies the verse even further. Rị̣ā comments:

The word 'two angels' is recited in two ways, with an a-vowel over the lām (malakayn) and with an i-vowel (malikayn). The first is the majority reading, and the second is the reading of Ibn 'Abbās, al-Ḥasan, Abū 'l-Aswad and al-Ḍaḥạ̄k. Some of them recited it malakayn as if it carried the meaning of malikayn, in which case what is being said is that the intended meaning by using the dual is David and Solomon (peace be upon them). It was said that the two men were dignified (șăhiba $w a q \bar{a} r)$, and they were called [angels] as they were being likened to angels. The people used to go to see the two of them for their family needs, and they honoured the two of them with great reverence, and they were like kings (mulük), which is the habit of the people, when they say that someone has commendable characteristics (al-ṣifāt al-mahmmüda). They would say: 'This is an angel (malak), not a person'. ('Abduh and Riḍā 2002, vol. 1, p. 349)

This short passage contains a number of different ideas and alludes to the description of Joseph as 'a noble angel' by the women of the city in Q. 12:31. First, Ridā introduces a variant reading ( $q i \bar{a}^{\prime} a$ ) which vocalizes the rasm as malikayn, meaning 'the two kings'. This variant reading is well attested (Umar and Mukarram 1988, vol. 1, p. 95), and appears in a number of exegeses in the classical period. However, it was not commonly accepted; for example, after giving the reading of malikayn, al-Tabarī (d. 320/923) comments:

Abū Ja'far [al-Tabarī] said: It was narrated from some of the reciters that it was recited and what was revealed [in Babylon] to the two kings Harut and Marut' meaning [they were] two men from among the children of Adam. We have shown the error of this reading, from the perspective gained through the inference of its context (istidlāl). However, from the perspective of the transmission of this reading, the consensus of the evidence [against it] indicates the error of its reading [seen in evidence from] the Companions, the Followers, the regional reciters; that is sufficient testimony of its error. (al-Tabarī 1984, vol. 1, p. 459)

Here, al-Ṭabari rejects the variant reading, and more generally the classical exegetical tradition did not take the variant reading malikayn seriously. This means that in the Mabhath al-siḥr, Riḍā is utilizing the variant reading, but goes against its reception in the broader, classical tafsīr tradition. 
Riḍā then goes on to state that there were those who, while reading the word as malakayn, nevertheless interpreted it as malikayn. This idea does appear elsewhere in the tafsīr tradition, and it is likely that 'Abduh/Riḍa had taken it from al-Ālūsī, who was of great interest to scholars such as Rị̂a (Pink 2016); indeed, this particular passage in the Mabhath al-sihr seems to draw heavily on al-Ālūsī's wording (al-Ālūsī 2005, vol. 1, p. 341). The position that even if the word is read as malakayn it is interpreted as malikayn seeks to weaken the divine origin of Hārūt and Mārūt. It is no surprise, therefore, that the mythic story of their seduction by Zuhara, which locates their origin as angels in heaven, is not included in the Tafsīr al-Manār. Ridā then cites a comment of 'Abduh which seeks to demystify and demythologize the passage completely; 'Abduh says: 'Perhaps God called them angels in the story to make people believe in them' ('Abduh and Ridā 2002, vol. 1, p. 349). Here, 'Abduh is using majāz to argue that the term is being used as a kind of honorific, although it is unclear why they should have received such an exalted status. Ridā then adds that 'Abduh favoured the metaphorical reading of malakayn, meaning that the word angels is being used to describe humans ( 'Abduh and Ridāa 2002, vol. 1, p. 349). The position that Hārūt and Mārūt were not angels goes against the vast majority of the tafsīr tradition which clearly understood Hārūt and Mārūt as being angels; by saying that they are human, the two beings are no longer angels and what they teach is not something they brought with them from the divine world.

This section on Hārūt and Mārūt then moves to a re-evaluation of the verb unzila ('sent down') which is the verb that governs Hārūt and Mārūt in Q. 2:102. This section seeks to prove that the use of the root $n-z-l$ in the Qur'ān does not always refer to revelation from God. Riḍā cites 'And we sent down iron' (Q. 57:25); 'Then God made his serenity descend upon His Messenger and the believers' (Q. 9:26); 'Your Lord inspired the bees' (Q. 16:68); 'To the mother of Moses we revealed: 'Give him to suck' (Q. 28:7); and 'demons of humans and Jinn. Each inspires to each vanities of speech, all of it delusion' (Q. 6:112) ('Abduh and Riḍā 2002, vol. 1, p. 350). These are all examples where the root is used to refer to something other than a divine 'sending down' of revelation. This seeks to demystify the angelic origin of Hārūt and Mārūt even further: not only are they now humans not angels, but they are also not the receivers of divine knowledge.

The Teacher, the imam, approved of this weakening of the position, on the basis that it was possible that the intended meaning could be to deny the sending down [of magic], meaning that that magic which is ascribed to the two angels was not sent down to them as a revelation from God. The Jews have categorized [magic] as one of the praiseworthy sciences, and they claim that it is real; but it is really something that they concocted (iftajara) and created of their own account. ('Abduh and Riḍā 2002, vol. 1, p. 350)

This is the core aim of the Mabhath al-sihr: to remove any association of magic with God, and to make Hārūt and Mārūt human. By doing so, the power and efficacy of magic becomes nullified, since it has no transcendent or supernatural origin. Rị̂a states explicitly that God, 'having denied the power' that lies behind the two angels, establishes a warning about the harm that magic can generate ('Abduh and Rị̣ā 2002, vol. 1, p. 352). Riḍā goes as far as to liken the use of magic to worshipping idols, emphasizing the harsh punishment that awaits those who practice it ('Abduh and Rị̣ā 2002, vol. 1, p. 352).

In many respects 'Abduh and Riḍā do not entertain the reading malikayn particularly seriously, and it is never used to refer to kings in any way, but they use the variant reading to place Hārūt and Mārūt firmly in the human realm, removing any trace of their divine origin, seen in the exegetical and folkloric accounts of their seduction by Zuhara. By further refuting the divine origin of anything that the two, now human beings, teach, and through the warning of the punishment that awaits those who practice magic, Hārūt and Mārūt are fully removed from their origin as angels from the divine world, and the magic that they teach does not have its origin in the divine world either. 


\section{The Influence of Biblical Criticism on the Demystification of Hārūt and Mārūt}

Muslim interest in biblical criticism owes much of its origins to nineteenth century Muslim defences against Christian missionary activity and Muslim polemic against Christian thought. The dominance of colonial powers, particularly the British in India, saw increased Christian proselytization among Muslim communities. However, the nineteenth century saw a significant shift in Muslim engagement with Christian thought, with the Indian Shī'ì theologian Raḥmatullāh Kayranāwī/Kayranāvī (d. 1308/1891) being the leading figure. Kayranāwī's Izhār al-haqq ('The Demonstration of the Truth'), published in 1853, was hugely influential, as it was translated into a vast array of languages and was read extremely widely (Ramsey 2017). Kayranāwī's most significant contribution was his use of European biblical criticism to generate attacks against Christian views of the Bible.

Muslim theologians had long attacked the Bible for tahriff, the doctrine in which Jews and Christians, although recipients of a divine scripture (kitäb) from God, are said to have corrupted and distorted it, introducing beliefs and ideas that should not belong in the scripture (Whttingham 2018). Schirrmacher comments that in the nineteenth century

a new wave of criticism emerged in Europe and quick found its way into the Muslim world. In European universities all miracles reported in the Old and New Testaments were called into question; historical events were doubted; the formulation of Christianity, the Trinity, and the deity of Jesus Christ, His crucifixion and resurrection were discussed from their very foundation. All these doubts and critical remarks of European theology found their way into the Muslim world and were enthusiastically taken as proofs of the traditional Muslim view of a corrupted Christian bible. (Schirrmacher 1999, p. 274)

Kayranāwī took this liberal scholarship and used it to attack Christian missionaries and anti-Muslim polemicists. At a famous debate with the Christian Missionary Karl Gottlieb Pfander (d. 1865) in Agra in 1854, this came as something of a surprise (Schirrmacher 1999, p. 274). Through Kayranāwī's I $z h \bar{a} r$ al-haqq and inspired by its approach, scholars throughout the Muslim world became aware of aspects of liberal European biblical criticism, especially those who were engaged with Christian missionaries.

Riḍā knew Kayranāwī's Iẓhār al-haqq well and frequently cited it in his articles in the Majallat al-Manār, as well as using it in the Tasfír al-Manār in passages that concerned Christianity (Schirrmacher 1999, p. 273). Riḍā was not able to read any European languages and had only a basic grasp of Turkish (Ryad 2009a, p. 24), but he established a strong network of scholars who translated European works on biblical criticism into Arabic, many of which were published in al-Manār. He also had many contacts who attended conferences of biblical studies, who would then provide descriptions of them in Muslim journals (Ryad 2009a, pp. 23-65). Consequently, Rị̂a had a firm knowledge of the methods and debates happening in biblical studies in the late 19th and early 20th centuries, which he then often used to attack Christian thought. From Riḍā's writings it is also clear that he, and many other Muslim scholars, actively engaged with Christian missionary activity in the region, with Riḍa often writing articles to address the allegations made against Islam by the missionaries (Womack 2015; Ryad 2009a, pp. 125-74).

However, what has not yet been explored in much detail is the extent to which this liberal European approach to interpreting and understanding scripture had an influence on Muslim scholars' own study of the Qur'ān. In her study of the reception of European biblical criticism in the Muslim world, Schirrmacher focuses on the use of biblical criticism in anti-Christian polemic, such as in Riḍā's arguments against Jesus's crucifixion. Riḍa had published the Gospel of Barnabas, a work that describes Judas taking Jesus' place on the cross, and he utilizes this source in his exegesis of the crucifixion verse (Q. 4:157; see Leirvik 2002), arguing that this text shows that the Christian accounts are confused (Schirrmacher 1999, p. 274). However, did aspects of biblical criticism appeal to 'Abduh's and Riḍā's modernist worldview beyond its application in anti-Christian polemic?

Looking at the approach taken by 'Abduh and Ridā to the supernatural and the magic 'performed' by the magicians at Pharoah's court in the Mabhath al-sihr, there are striking 
similarities to the responses to the same episode made by European biblical scholars. The early German scholar, Hermann Strack, wrote in 1894

Noch jetzt gibt es in Ägypten Schlangenbändiger, deren Kunst es zuwege bringt, daß eine Schlange erst bewegungslös wie ein Stodt wie erscheint (man vergleiche die durch hynoptisieren hervorgebrachte Starrheit) und dann sich wieder bewegt. [Even now there are snake-charmers in Egypt whose art makes it possible for a snake to first appear motionless like a dead man (compare the rigidity brought about by hypnotizing) and then to move again']. (Strack 1894, p. 184)

Here, Strack makes allusions to contemporary 'mesmerism' and also some local context with his reference to contemporary Egyptian snake charmers. Similarly, S.R. Driver in his Commentary on Exodus, written in 1911, comments

The art of serpent charming is indigenous in the East: there are allusions to it in Ps. Lviii.5, Jer. Vii.17, Eccl. X, 11; and it is practised in Egypt to the present day. Modern Egyptian serpent charmers possess an extraordinary power over serpents, drawing them forth, for instance, by noises made with the lips, from their hiding-places, and by pressure applied to the neck throwing them into such a state of hynoptic rigidity that they can be held as rod by the tip of the tail (Lane, Mod. e.g., ch. Xx ... ). The serpent commonly used is a species of cobra. As Di., however, remarks, we hear elsewhere of serpents become rods, not of rod becoming serpents: the latter, as also the swallowing up of the magicians' rods by Aaron's rod is 'peculiar to the Hebrew story' (Sage). (Driver 1911, p. 52)

Driver here refers to Edward Lane's Manners and Customs of the Egyptians, which describes several tricks used by snake charmers in Egyptian markets, which Lane explains through rational means (Lane 2003, pp. 383-86). What is important, here, is that the Mabhäth al-sihr adopts a similar approach to explaining instances of magic in the Qur'ān. There is an attempt to contextualize the material within the social context, i.e., the Sitz im Leben, but also to ensure that readers are fully aware that what is going on is not magical in any sense. The Mabhäth al-sihr does not (perhaps oddly) refer to snake charmers, but it does refer to the use of mercury to produce a snake-like rod ('Abduh and Rị̂a 2002, vol. 1, pp. 347-48). Both scholars of the Bible and Muslim modernists can be seen seeking to demystify the supernatural: rational and logical explanations are given for things that are referred to as being 'magical' in scripture.

The treatment of the magic pericope seems to suggest that aspects of liberal European biblical scholarship were not simply being used to advance anti-Christian polemics but came to influence the way in which Muslim scholars approached aspects of the Qur'ān too. The extent to which this can be seen in a work such as the Tafsitr al-Manār needs further and more detailed research, but it raises interesting questions about the impact of Western biblical scholarship on Islam. Interestingly, such an approach may also reflect an internal polemic, where the reformists are critiquing Muslims who still wish to defend the traditional and seemingly 'irrational' elements found in the Qur'ān. The position against the divine origin of Hārūt and Mārūt or the magical powers of Solomon advanced by 'Abduh and Rị̣a are also aimed at those Muslims who maintain that position. The techniques and methods of liberal European biblical criticism are used not just to attack Christian claims about the Bible, but they are also used to develop reformist discourses in Islam.

\section{Conclusions}

This article has attempted to provide an exegetical and homiletic analysis of the passage against magic entitled Mabhath al-sihr wa-Hārüt wa-Mārüt, which forms the majority of the exegetical response to the Qur'ānic magic pericope in 'Abduh and Riḍā's Tafsìr al-Manār. What is clear is that the Mabhath al-sihr is primarily homiletic and polemic, rather than exegetical. The aspects of exegesis that are utilized in this section are wholly subservient to the wider points being made against the use and efficacy of magic. The clear 
objective of the passage is to denounce magic and to show that it does not really exist. To this end, they employ a number of arguments to achieve their aim, some of which have their origin in the tafsìr tradition, but many of which do not.

There is a clear attempt to demystify all references to magic that appear in the Qur'ān and Muslim tradition. This is achieved by applying broader metaphorical definitions to the lexical terms that are used for magic. It is also achieved through the integration and addition of psychological understandings of magic: the viewer may regard a trick as being 'magical', but it is simply a trick and an illusion. This process of demystification can be also seen in the liberal biblical scholarship that emerged in Europe from the late nineteenth century onwards, particularly amongst Christian scholars. The move into modernity and the development of scientific advances saw a desire to rationalize the Bible and to make sense of passages that appeared irrational in light of scientific knowledge (Rogerson 2006). Whether the move to demystify seen in this section of the Tafsì al-Manār is the same process as what came to be known as demythologization, as pioneered by figures such as Rudolf Bultmann, is a much more complex question (cf. Abu Shareea 2019). Writing towards the end of his career, Bultmann gives his own definition of demythologization, saying 'By "demythologizing" I understand a hermeneutical procedure that inquires about the reality referred to by mythological statements or texts. This presupposes that myth indeed speaks of a reality, although in an inadequate way' (Bultmann 1960, p. 62). As a way of reading the Bible, demythologization seeks to remove supernatural and historical claims in myth and to reduce them to their moral and ethical messages. The Mabhath al-sihr seems to suggest a similar approach, as was seen above in 'Abduh's description of the function and purpose of scripture:

We have shown, more than once, that stories appear in the Qur'ān to teach and to generate reflection, they are not there to explain history, nor to bring about belief in the minutiae of the accounts about ages past, but, rather, it is to come to a judgement about what can be understood regarding truth and falsehood, [what can be understood about] the truth and falsehoods in their narrations, and which of their customs were beneficial and [which were] damaging - for that reason they are for teaching and reflection. ('Abduh and Ridā 2002, vol. 1, pp. 346-47)

This way of reading the Qur'ān is remarkably similar to the approach to myth being pursued in biblical scholarship. However, it is possible that the demystifying and demythologizing seen in the Mabhath al-sihr was simply a useful tool in the polemic against magic, and further research is needed to explore the extent to which 'Abduh and Riḍa utilize demythologization in their treatment of Qur'ānic myth.

At the same time, it is important to acknowledge that 'Abduh and Ridāa are deeply indebted to the broader Muslim tradition in their discourse against magic. For example, the rejection of magic (sihr) was commonly advocated by classical theologians, most prominently by Mu'tazilīs, and 'Abduh/Riḍa appear to be drawing on this body of material in their own discourse, which fits in with the scholarly understanding of 'Abduh's engagement with Mu'tazilī thought (see Çoruh 2019, pp. 8-9). 'Abduh also adds a further dimension to these classical arguments against magic by using psychology to explain the way in which individuals who see illusions interpret them as magic (see Mol 2013, p. 22). Similarly, the rejection of Isrä'iliyyāt material was common in Muslim thought, particularly after Ibn Taymiyya (see Tottoli 1999), but Riḍa extends the rejection of this material and develops a stronger, more general discourse against Jewish thought. 'Abduh and a number of other Muslim thinkers in the late 19th and early 20th centuries were also concerned about the reliability of hadith (see Çoruh 2019, pp. 5-8), which lies behind much of the rejection of beliefs about Solomon and magic in the Mabhath al-sihr. 'Abduh and Ridā's engagement with the qira' $\bar{a} t$ material also shows their engagement with the broader tafsi $\bar{r}$ tradition, even though 'Abduh uses it in an 'unorthodox' manner.

The oral origins of the Tafsīr al-Manār are clearly present in the Mabhath al-sihr wa-Hārüt wa-Mārüt: there are a number of elements that show rhetorical flourishes and homiletic devices. The use of personal testimony, a rare feature in the tafsìr tradition, is utilized to 
help draw listeners into accepting the arguments against magic. One of the most noticeable rhetorical and homiletic devices is the use of antisemitic tropes and arguments. The Jews are described as being devious and deceitful, they are alleged to have intentionally concocted and invented magic, and are accused of besmirching the name of the prophet Solomon by using him as a means to justify its use. The tone and tenor of the Mabhath al-sihr clearly taps into elements of antisemitism that were prevalent in the early 20th century both in Egypt and Europe. Although the Tafsìr al-Manār is an exegesis, drawn from the oral lectures of Muhammad 'Abduh, the Mabhath al-sihr wa-Hārūt wa-Mārüt is essentially an independent, discrete polemic 'tract' contained within it. The way the passage is constructed is clearly homiletic, rather than exegetic, with the sole aim being to argue that magic simply does not exist.

Although the term eisegetical is usually used pejoratively, that is exactly what is happening in this short tract: the elements of exegetical thinking which are included are used as prooftexts to deny the existence of magic, rather than allowing the text to lead the investigation. The homiletic approach changes the form, substance, and tone of the material, and allows the easy introduction of polemic. Indeed, the elements of antisemitism that are present in the tract form a key component in the construction of the argument made against magic. This is seen particularly strongly in one line within the text that states: 'The Jews have categorized [magic] as one of the praiseworthy sciences, and they claim that it is real; but it is really something that they concocted and created of their own account' ('Abduh and Rida 2002, vol. 1, p. 350). The whole aim of the tract to deny the existence of magic and to blame its existence on the Jews, which raises some interesting and difficult questions. That aside, this short tract provides an intriguing window into modernist unease with aspects of the supernatural found in the Qur'ann and popular culture, and especially with magic. It also shows that modernist biblical and Qur'ānic exegetes were both seeking solutions to the 'magical' in scripture; modernist Jews, Christians, and Muslims sought ways to demystify elements of scripture in a bid to make ancient texts palatable in light of modern thinking and scientific advances.

Funding: The research received no external funding.

Institutional Review Board Statement: Not applicable.

Informed Consent Statement: Not applicable.

Data Availability Statement: Not applicable.

Conflicts of Interest: The author declares no conflict of interest.

\section{References}

'Abduh, Muhammad, and Muhammad Rashīd Riḍā. 2002. Tafsīr al-Qur'ān al-'Aẓīm al-ma 'rūf bi-Tafsīr al-Manār. Edited by Samīr Muștafā Rabāb. Beirut: Dār Ihyā' al-Turāth al- 'Arabiyy.

Abu Shareea, Mohammad. 2019. On the edge of Bultmann's demythologisation: Muhammad 'Abduh's hermeneutical Avicennism on the Qur'an as a source of scientific knowledge. Australian Journal of Islamic Studies 4: 54-71.

Adams, Charles Clarence. 2010. Islam and Modernism: A Study of the Modern Reform Movement inaugurated by Muhammad Abduh. Kuala Lumpur: Islamic Book Trust.

al-Ālūsī. 2005. Rūḥ al-ma 'ānī. Edited by 'Alī 'Abd al-Bārī' Ațiyya. Beirut: Dār al-Kutub al- 'Tlmiyya.

al-Rabghūzī. 1995. The Stories of the Prophets: Qisas al-Anbiya-An Eastern Turkish Version. Edited by Hendrik Boeschoten. Leiden: Brill. al-Ṭabarī. 1984. Jāmi' al-bayān 'an ta'wōl al-Qur'ān. Beirut: Dār al-Fikr.

al-Tha 'labī. 2002. Arā'is al-majālis fí qișas al-anbiyā' or the "Lives of the Prophets". Translated by William M. Brinner. Leiden: Brill.

Bashkin, Orit. 2021. The Colonized Semites and the Infectious Disease: Theorizing and Narrativizing Anti-Semitism in the Levant, 1870-914. Critical Inquiry 47: 189-217. [CrossRef]

Bauckham, Richard. 1985. The Fall of the Angels as the Source of Philosophy in Hermias and Clement of Alexandria. Vigiliae Christianae 39: 313-30. [CrossRef]

Berkey, Jonathan Porter. 1995. Tradition, innovation and the social construction of knowledge in the medieval Islamic Near East. Past and Present 146: 38-65. [CrossRef]

Blatherwick, Helen. 2016. Prophets, Gods and Kings in Sīrat Sayf ibn Dhī Yazān. Leiden: Brill.

Bultmann, Rudolf. 1960. On the problem of demythologizing. The Journal of Religion 42: 96-106. [CrossRef] 
Burge, Stephen Russell. 2012. Angels in Islam: Jalāl al-Dīn al-Suyūțī's al-Habā'ik fī akhbār al-malā'ik. London: Routledge.

Burge, Stephen Russell. 2015. Jalal al-Din al-Suyuti, the Mu'awwidhatan and the Modes of Exegesis. In Aims, Methods and Contexts of Qur'anic Exegesis (2nd/8th-9th/15th C). Edited by Karen Bauer. London: Oxford University Press, pp. $277-307$.

Burge, Stephen Russell. 2017. Islamic. In The Bible in Folklore Worldwide. I. A Handbook of the Bible and Its Reception in Jewish, European Christian, and Islamic Folklores. Edited by Eric Ziolkowski. Berlin: De Gruyter, pp. 307-30.

Burge, Stephen Russell. 2021. Angelology and Anthropology: The "Fall" of the Angels Harut and Marut and the Meaning of Being Human. In Medieval Angelology in Judaism, Christianity and Islam: Interfaith Convergences in Abrahamic Spirituality and Culture. Edited by June-Ann Greeley. Cardiff: University of Wales Press.

Burge, Stephen Russell. forthcoming. Harut and Marut. In Encyclopaedia Islamica. Leiden: Brill.

Commins, David D. 2006. Al-Manār and popular religion in Syria, 1898-920. In Intellectuals in the Modern Islamic World: Transmission, Transformation, Communication. Edited by Stephane A. Dudoignon, Komatsu Hisao and Kosugi Yasushi. London: Routledge, pp. $40-54$.

Çoruh, Hakan. 2019. The Qur'ān and interpretation in the classical modernism; Tafsircentric approach of Muhammad 'Abduh. Australian Journal of Islamic Studies 4: 1-21.

Dols, Michael W. 1992. Majnūn: The Madman in Medieval Islamic Society. Oxford: Oxford University Press.

Driver, Samuel Rolles. 1911. The Book of Exodus. Cambridge: Cambridge University Press.

Dennis C. Duling, trans. 1983, The Testament of Solomon. In The Old Testament Pseudepigrapha. Charlesworth, James H., ed. London: Darton, Longmann and Todd, vol. 1, pp. 935-87.

Elissa-Mondeguer, Nadia. 2002. Al-Manâr de 1925 à 1935: La dernière décennie d'un engagement intellectual. Revue des Mondes Musulmanes et de la Méditerranée 95-98: 205-36. [CrossRef]

Elshakry, Marwa. 2011. Muslim hermeneutics and Arabic views of evolution. Zygon 46: 330-44. [CrossRef]

Fastenbauer, Raimund. 2002. Islamic antisemitism: Jews in the Qur'an, Reflections of European antisemitism, Political anti-Zionism: Common codes and differences. In Confronting Antisemitism from the Perspectives of Christianity, Islam, and Judaism. Edited by Armin Lange, Kerstin Mayerhofer, Dina Porat and Lawrence H. Schiffma. Berlin: De Gruyter, pp. $279-99$.

Fodor, Alexander. 1978. The rod of Moses in Arabic magic. Acta Orientalia 32: 1-21.

Francis, Edgar. 2019. Magic and Magicans, VI. Islam. In The Encyclopaedia of the Bible and Its Reception. Berlin: De Gruyter, vol. 17, coll. 471-73.

Hamès, Constant. 2017. Coran et Talismans: Textes et Pratiques Magiques en Milieu Musulman. Paris: Karthala.

Jones, Linda G. 2012. The Power of Oratory in the Medieval Muslim World. Cambridge: Cambridge University Press.

Kerr, Malcolm H. 1966. Islamic Reform: The Political and Legal Theories of Muhammad 'Abduh and Rashīd Ridā. Berkeley: University of California Press.

Khalidi, Tarif. 2008. The Qur'an. London: Penguin.

Klar, Marianna O. 2006. "And we cast upon his throne a mere body": A historiographical reading of Q. 38: 34. Journal of Qur'anic Studies 6: 103-26. [CrossRef]

Lamont, Peter. 2017. A particular kind of wonder: The experience of magic past and present. Review of General Psychology 21: 1-8. [CrossRef]

Lane, Edward William. 1984. Arabic-English Lexicon. Cambridge: Islamic Texts Society.

Lane, Edward William. 2003. An Account of The Manners and Customs of the Egyptians: The Definitive 1860 Edition. Edited by Jason Thompson. Cairo: American University of Cairo Press.

Leirvik, Oddbjørn. 2002. History as a literary weapon: The Gospel of Barnabas in Muslim-Christian polemics. Studia Theologica 56: 4-26. [CrossRef]

Memon, Muhammad Umar. 1976. Ibn Taimīya's Struggle against Popular Religion. The Hague: Mouton.

Moad, Edward. 2017. The jinn and shayātīn. In Philosophical Approaches to Demonology. Edited by Benjamin W. McCraw and Robert Arp. London: Routledge, pp. 137-55.

Mol, Arnold Yasin. 2013. The denial of supernatural sorcery in classical and modern Sunnī tafsīr of Süra al-Falaq (113,4): A reflection on underlying concerns. al-Bayān 11: 15-32.

Nettler, Ronald L. 1999. Early Islam, Modern Islam and Judaism: The Isra'iliyyat in Modern Muslim thought. In Muslim-Jewish Encounters: Intellectual Traditions and Modern Politics. Edited by Ronald L. Nettler and Suha Taji-Farouki. Amsterdam: Harwood Academic Publishers, pp. 1-14.

O'Connor, Kathleen M. 2016. Popular and Talismanic Uses of the Qur'an. The Encyclopaedia of the Qur'ān. Available online: http:/ / dx.doi.org.iij.idm.oclc.org/10.1163/1875-3922_q3_EQCOM_00152 (accessed on 31 August 2021).

Pink, Johanna. 2016. Rashīd Rị̣ā. The Encyclopaedia of the Qur'ān. Available online: http://dx.doi.org.iij.idm.oclc.org/10.1163/1875 -3922_q3_EQCOM_050503 (accessed on 31 August 2021).

Ramsey, Charles M. 2017. Kairanāwī, Rahmat Allāh. In The Encyclopaedia of the Bible and Its Reception. Berlin: De Gruyter, vol. 14, coll. 1226-27.

Reed, Annette Yoshiko. 2004. Heavenly Ascent, Angelic Descent, and the Transmission of Knowledge in 1 Enoch 6-16. In Heavenly Realms and Earthly Realities in Late Antique Religions. Edited by Ra'anan S. Boustan and Annette Yoshiko Reed. Cambridge: Cambridge University Press, pp. 47-66.

Rị̣ā, Rashīd. 1928. Thawrat Filisțīn. Majallat al-Manār 30: 385-87. 
Rogerson, John W. 2006. The Modern World. In The Blackwell Companion to the Bible and Culture. Edited by John F. A. Sawyer. Oxford: Blackwell, pp. 104-16.

Ryad, Umar. 2009a. Islamic Reformism and Christianity: A Critical Reading of the Works of Muhammad Rashīd Ridā and His Associates (1898-1935). Leiden: Brill.

Ryad, Umar. 2009b. Printed Muslim ‘Lighthouse' in Cairo: Al-Manār's Early Years, Religious Aspiration and Reception (1898-1903). Arabica 56: 27-60. [CrossRef]

Scharbrodt, Oliver. 2007. The Salafiyya and Sufism: Muhammad 'Abduh and his Risālat al-Wāridāt (Treatise on Mystical Interpretations). Bulletin of the School of Oriental and African Studies 70: 89-115. [CrossRef]

Schirrmacher, Christine. 1999. The influence of German biblical criticism on Muslim apologetics in the nineteenth century. In Muslim Perceptions of Other Religions. Edited by Jacques Waardenburg. Oxford: Oxford University Press, pp. 270-79.

Shavit, Uriya. 2015. Zioinism as told by Rashīd Riḍā. Journal of Israeli History 34: 23-44. [CrossRef]

Shrenzel, Israel. 2002. Against the mainstream: Muhamamd 'Abduh's reading of Q 1:7 and its implications for Current Muslim-Jewish relations. In Confronting Antisemitism from the Perspectives of Christianity, Islam, and Judaism. Edited by Armin Lange, Kerstin Mayerhofer, Dina Porat and Lawrence H. Schiffma. Berlin: De Gruyter, pp. 209-21.

Sirriyeh, Elizabeth. 2000. Rashid Rida's autobiography of the Syrian years, 1865-97. Arabic and Middle Eastern Literatures 3: 179-94.

Smith, Andrew C. 2018. Moses and Pharaoh's Magicians: A Discursive Analysis of the Qur'anic Narratives in the Light of Late Antique Texts and Traditions. Journal of Qur'anic Studies 20: 67-104. [CrossRef]

Smith, Gerald Rex. 1995. Magic, jinn and the supernatural in medieval Yemen: Examples form Ibn al-Muğāwir's 7th/13th century guide. Quaderni di Studi Arabi 13: 7-18.

Strack, Hermann L. 1894. Die Bücher Genesis, Exodus, Leviticus und Numeri. Munich: C. H. Bed'sche Verlagsbuchhandlung.

Thomas, David. 2011. Miracles in Islam. In The Cambridge Companion to Miracles. Edited by Graham Twelfttree. Cambridge: Cambridge University Press, pp. 199-215.

Torijano, Pablo. A. 1999. Solomon the Esoteric King: From King to Magus, Development of a Tradition. New York: New York University Press. Tottoli, Roberto. 1999. Origin and Use of the Term isrä'îliyyāt in Muslim Literature. Arabica 46: 193-210. [CrossRef]

Umar, Aḥmad Mukhār, and 'Abd al- 'Āl Sālim Mukarram, eds. 1988. Mu 'jam al-qirā'āt al-Qur'ān. Kuwait: Maṭba 'āt Jāmi 'at al-Kuwayt.

Whttingham, Martin. 2018. Muslims and the Bible. In The Routledge Handbook on Christian-Muslim Relations. Edited by D. Thomas. London: Routledge, pp. 269-78.

Williams, Rebecca. 2013. Muhammad and the Supernatural: Medieval Arab Views. London: Routledge.

Womack, Deanna Ferree. 2015. The authenticity and authority of Islam: Muhammad Rashid Rida's response to Twentieth-century missionary publications. Social Sciences and Missions 25: 89-115. [CrossRef]

Yasushi, Kosugi. 2006. Al-Manār revisited: The "lighthouse" of the Islamic revival. In Intellectuals in the Modern Islamic World: Transmission, Transformation, Communication. Edited by Stephane A. Dudoignon, Komatsu Hisao and Kosugi Yasushi. London: Routledge, pp. 3-39.

Zadeh, Travis. 2009. Touch and ingesting: Medieval debates over the material Qur'an. Journal of the American Oriental Society 129: 443-66.

Zadeh, Travis. 2015. Magic, marvel, and miracle in early Islamic thought. In The Cambridge History of Magic and Witchcraft in the West: From Antiquity to the Present. Edited by David J. Collins. Cambridge: Cambridge University Press, pp. $235-67$.

Zaman, Muhammad Qasim. 2012. Modern Islamic Thought in a Radical Age: Religious Authority and Internal Criticism. Cambridge: Cambridge University Press.

Zebiri, Kate. 2000. Contemporary Muslim understanding of the miracles of Jesus. The Muslim World 90: 71-90. [CrossRef]

Zemmin, Florian. 2017. Modernity in Islamic Tradition: The Concept of 'Society' in the Journal al-Manar Cairo, (1898-1940). Berlin: De Gruyter. 